Cl oning of two members of the cal ci t oni n- fami l y r ecept or s from st i ngr ay, Dasyat is akaj ei : Possi bl e physi ol ogi cal rol es of the cal citoni $n$ family i n osmor egul at $i$ on

\begin{tabular}{|c|c|}
\hline 著者 & $\begin{array}{l}\text { Suzuki Nobuo, Seki guchi Toshi o, Sat ake Honoo, } \\
\text { Kat o Kanoko, N shi yana Yudai, Takahashi } \\
\text { H deya, Dankse Jani ne A., Nart i n T. John, } \\
\text { Hat tor i At suhi ko, Nakano Nasaki, Kaki kawa } \\
\text { Naki ko, Yamada Sot oshi, Ogoshi Naho, Hyodo } \\
\text { Susumu, Yamaguchi Yoko, Chowdhur Vi shwaj i t S., } \\
\text { Hayakawa Kazui chi, Funahashi Hi sayuki, } \\
\text { Sakamot o Tat suya, Sasayama Yui chi }\end{array}$ \\
\hline $\begin{array}{l}\text { j our nal or } \\
\text { publ i cat } i \text { on } t i t l e\end{array}$ & Gene \\
\hline vol une & 499 \\
\hline number & 2 \\
\hline page $r$ ange & $326-331$ \\
\hline year & $2012-05-15$ \\
\hline URL & ht t p: //hdl . handl e. net /2297/31368 \\
\hline
\end{tabular}




\section{Cloning of two members of the calcitonin-family receptors from stingray, Dasyatis akajei: Possible physiological roles of the calcitonin family in osmoregulation}

Nobuo Suzuki $^{\mathrm{a}^{*}}$, Toshio Sekiguchi ${ }^{\mathrm{b}}$, Honoo Satake ${ }^{\mathrm{b}}$, Kanoko Kato $^{\mathrm{c}}$, Yudai Nishiyama ${ }^{\mathrm{c}}$, Hideya Takahashi ${ }^{\mathrm{c}, \mathrm{d}}$, Janine A. Danks ${ }^{\mathrm{e}}$, T. John Martin ${ }^{\mathrm{f}}$, Atsuhiko Hattori ${ }^{\mathrm{g}}$, Masaki Nakano $^{\text {g }}$, Makiko Kakikawa ${ }^{\text {h, Sotoshi Yamada }}{ }^{\text {h }}$, Maho Ogoshi ${ }^{\mathrm{c}}$, Susumu Hyodo, Yoko Yamaguchi $^{i}$, Vishwajit S. Chowdhury ${ }^{j}$ Kazuichi Hayakawak, Hisayuki Funahashim, Tatsuya Sakamoto $^{\mathrm{c}}$ and Yuichi Sasayama ${ }^{\mathrm{a}}$

${ }^{a}$ Noto Marine Laboratory, Institute of Nature and Environmental Technology, Kanazawa University, Housu-gun, Ishikawa 927-0553, Japan; ${ }^{b}$ Suntory Institute for Bioorganic Research, Mishima-gun, Osaka 618-8503, Japan; ' Ushimado Marine Institute, Okayama University, Ushimado, Okayama 701-4303, Japan; ${ }^{d}$ Institute of Science and Technology, Niigata University, Niigata 950-2181, Japan;

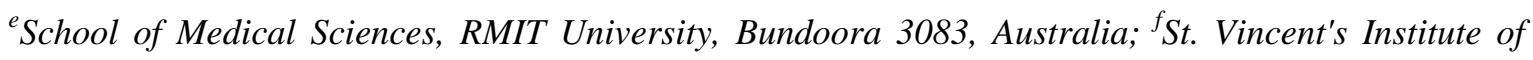
Medical Research, 41 Victoria Parade, Fitzroy 3065, Australia; ${ }^{g}$ Department of Biology, College of Liberal Arts and Sciences, Tokyo Medical and Dental University, Ichikawa-city, Chiba 272-0827; ${ }^{h}$ Institute of Nature and Environmental Technology, Kanazawa University, Kanazawa-city, Ishikawa 920-1192, Japan; ${ }^{i}$ Atmosphere and Ocean Research Institute, University of Tokyo, Kashiwa-city, Chiba 277-8564 Japan; ${ }^{j}$ International Education Center, Faculty of Agriculture, Kyushu University, Fukuoka 812-8581, Japan; ${ }^{k}$ Faculty of Pharmaceutical Science, Institute of Medical, Pharmaceutical and Health Sciences, Kanazawa University, Kanazawa-city, Ishikawa 920-1192; ${ }^{m}$ Showa University, School of Medicine, Department of Anatomy, Shinagawa-ku, Tokyo 142-8555, Japan

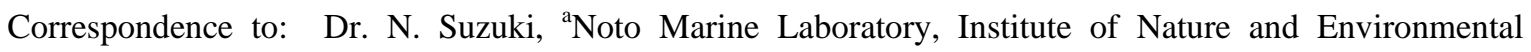
Technology, Kanazawa University, Ogi, Noto-cho, Ishikawa 927-0553, Japan. Tel.: 81-768-74-1151; Fax 81-768-74-1644; e-mail: nobuos@staff.kanazawa-u.ac.jp

Keywords: calcitonin; calcitonin gene-related peptide; tissue expression; elasmobranch

Abbreviations: bp, base pair(s); cDNA, DNA complementary to RNA; CGRP, calcitonin gene-related peptide; calcitonin, CT; calcitonin receptor, CTR; calcitonin-receptor-like receptor, CRLR; mRNA, messenger RNA; PCR, polymerase chain reaction; RACE, rapid amplification of cDNA ends; RT-PCR, reverse transcription-polymerase chain reaction. 
Abstract In cartilaginous fish, two cDNAs encoding calcitonin-family receptors were isolated for the first time from the stingray brain. The open reading frame of one receptor cDNA coded a 525-amino acid protein. The amino acid identity of this receptor to human calcitonin-receptor-like receptor (CRLR) is 64.5\%, frog CRLR is 64.7\%, and flounder CRLR is $61.2 \%$ and this was higher than to human calcitonin receptor (CTR) (46.1\%), frog CTR (54.7\%), and flounder CTR (48.9\%). We strongly suggested that this receptor is a ray CRLR based on phylogenetic analysis. In case of the second receptor, amino acid identity among CRLRs (human 50.5\%; frog 50.7\%; flounder 48.0\%) and CTRs (human 43.2\%; frog 49.1\%; flounder 41.8\%) was similar. From phylogenetic analysis of both CRLRs and CTRs, we believe that this receptor is ray CTR. The expression of ray CRLR mRNA was predominantly detected in the nervous system (brain) and vascular system (atrium, ventricle, and gill), which reflects the similar localization of CGRP in the nervous and vascular systems as mammals. It was observed that the second receptor was expressed in several tissues, namely cartilage, brain, pituitary gland, gill, atrium, ventricle, pancreas, spleen, liver, gall bladder, intestine, rectal gland, kidney, testis and ovary. This localization pattern was very similar to flounder CTR. Both receptor mRNAs were strongly expressed in the gill. This suggests that the calcitonin-family members are involved in the osmoregulation of stingray as this fish is known to be euryhaline. When a stingray was transferred to diluted seawater (20\% seawater), the expression of both receptors significantly decreased in the gill. Similar results were obtained in the kidney of the stingray. Thus, our cloning and isolation of both receptors in the stingray will be helpful for elucidation of their physiological role (s) such as osmoregulation including calcium metabolism of cartilaginous fish. 


\section{Introduction}

Calcitonin gene-related peptide (CGRP) is a 37 amino acid hormone whose mRNA is co-encoded with calcitonin (CT) mRNA on a single gene (Amara et al., 1982). In mammals, the mRNA synthesis of two hormones is controlled by tissue-specific alternative splicing; CGRP precursor mRNA is synthesized in the neural tissues; CT precursor mRNA is synthesized in the thyroidal C-cells (Rosenfeld et al., 1983). Since CGRP exists widely in the central nervous system (Rosenfeld et al., 1983; Gibson et al., 1984), it is suggested that CGRP plays role as a neuromediator or neuromodulator (Lafont et al., 2007). In addition, CGRP is synthesized in the heart and blood vessels to control blood flow by its potent vasodilatory actions (Mulderry et al., 1985; Wimalawansa, 1997; Brain and Grant, 2004).

In teleosts, the presence of CGRP immunoreactive substances has been demonstrated in trout (Fouchereau-Peron et al., 1990). Jansz and Zandberg (1992) characterized the CGRP gene of salmon, suggesting that salmon CGRP is the product of the alternative splicing of the CT/CGRP gene, common to mammals. We also cloned a part of genomic DNA including the CGRP gene from flounder (Paralichthys olivaceus) and detected mRNA expression in the brain and heart (Suzuki et al., 2001), suggesting that CGRP acts as a neuropeptide and a vasodilator in fish as well as mammals. As CGRP immunoreactivity has been detected in the brain of small-spotted dogfish (Molist et al., 1995), and may be quite important in homeostasis in all fish including cartilaginous fish (Lafont et al., 2007). On the other hand, calcitonin receptor-like receptor (CRLR) functions to a receptor for CGRP when it is co-expressed with RAMP1 (McLatchie et al., 1998; Husmann et al., 2000; Sexton et al., 2001). The distribution and expression analysis of CRLR under various physiological and environmental conditions could contribute to the understanding of physiological functions of CGRP in cartilaginous fish. 
To study the physiological role of CGRP in cartilaginous fish, the full coding region of CRLR was sequenced from the brain of stingray and the mRNA expression in the various tissues was analyzed. In the process of CRLR cloning, a second member of the calcitonin-family receptors was isolated and cloned. Based on the data of multiple alignment, phylogenetic analysis and tissue distribution pattern, it is apparent that this receptor is equivalent to the stingray calcitonin receptor (CTR). In addition, it was found that the expression of two receptors was decreased in the gill and kidney when the rays were transferred to diluted seawater. Thus, this is the first study that identifies two members of calcitonin-family receptors in cartilaginous fish and indicates the possible physiological roles of CT and CGRP in the osmoregulation of stingray.

\section{Materials and methods}

\subsection{Animals}

The brain of male stingray (Dasyatis akajei) was used for PCR amplification. Male and female stingrays were used for the analysis of tissue-specific expression and adaptation in seawater. The original concentration of seawater (100\%) and diluted seawater (20\%) were used for this study. The animals were anesthetized with ethyl 3-amino-benzoate, methanesulfonic acid salt (Sigma-Aldrich Inc., MO, USA) and then dissected for tissue preparation.

All experimental procedures were conducted in accordance with the Guide for the Care and Use of Laboratory Animals prepared by Kanazawa University.

\subsection{PCR amplification}

Total RNAs were prepared using a total RNA isolation kit (Nippon Gene, Tokyo, 
Japan) from the brains of stingray. RT-PCR was performed using Oligotex-dT 30 Super (Takara, Kusatsu, Japan) as an oligo dT primer to prevent genomic DNA contamination (Suzuki et al., 1997). The PCR primers were designed at the well-conserved region of the mammalian CRLR and CTR cDNA sequences (Figure 1). The primer sequences were: 5’A-GYAAYMGXACXTGGGAYGG; 5’B-GAYTAYTTYCCXGAYTTYGA; 3'A-CCYTCRCAXARCATCCARAA; 3’B:CATCCARAARTARTTRCA (Suzuki et al., 2000). The 1st and the nested-PCR (1st PCR: 5'A/3'A primer set; 2nd PCR: 5'B/3'B primer set) were performed using a Taq polymerase and an additional buffer (Takara Bio Inc., Otsu, Japan). The PCR parameters were 35 cycles of $96^{\circ} \mathrm{C}$ for $30 \mathrm{~s}, 45^{\circ} \mathrm{C}$ for $1 \mathrm{~min}$, and $72^{\circ} \mathrm{C}$ for $2 \mathrm{~min}$. The sequencing of the PCR products of the expected length (422 bp) was performed by Dragon Genomics Center, Takara Bio Inc. (Mie, Japan).

\subsection{RACE amplification of receptors cDNAs in stingray}

Total RNA ( $1 \mu \mathrm{g})$ was obtained from the stingray brain. The complete sequences of the two receptors were obtained by 5'- and 3'-RACE method using a kit 5' RACE System, Version 2.0 and 3' RACE System for Rapid Amplification of cDNA Ends, respectively (Invitrogen, CA, USA). The primer locations for two receptors were described in supplementary figures. RACE was performed using the respective gene-specific primer and the primer of adaptor sequences in the kit. The products were sequenced on an ABI PRISM 3130 sequencer (Applied Biosystems, CA, USA) using BigDye terminators.

\subsection{Expression analysis}

Total RNAs were prepared from the cartilage, brain, pituitary gland, gill atrium, ventricle, pancreas, spleen, liver, gall bladder, intestine, rectal gland, kidney, and testis of 
male stingray, as well as the ovary of female stingray using a total RNA isolation kit (Nippon Gene). RT-PCR was performed using the primer set (CRLR 5’AGACTTCGATCCATCAGA; CRLR 3’: AGTCAATGCTGTCTTTA; CTR-like 5’: CACGGAAAAGGTCACC; CTR-like 3’: AgTGAACAAAGAGTAATAT). The conditions for PCR amplification were 40 cycles of denaturation for $0.5 \mathrm{~min}$ at $96^{\circ} \mathrm{C}$, annealing for $1 \mathrm{~min}$ at $60^{\circ} \mathrm{C}$, and extension for $2 \mathrm{~min}$ at $72^{\circ} \mathrm{C}$, followed by a single cycle at $72^{\circ} \mathrm{C}$ for $30 \mathrm{~min}$. In case of the $\beta$-actin cDNA (AB675482), the amplification using a

primer set $\quad$ (5’ $^{\prime}$ sTGGCAATGAGCGATTCAGA; $\quad$ 3’: CACAGGATTCCATACCCAAGAAA) were consisted of 25 cycles of denaturation for $0.5 \mathrm{~min}$ at $96^{\circ} \mathrm{C}$, annealing for $1 \mathrm{~min}$ at $60^{\circ} \mathrm{C}$, and extension for $2 \mathrm{~min}$ at $72^{\circ} \mathrm{C}$, followed by a single cycle at $72{ }^{\circ} \mathrm{C}$ for $15 \mathrm{~min}$. The PCR products were analyzed on $2.5 \%$ NuSive GTG agarose gel (FMC Bioproducts, ME, USA) and stained with ethidium bromide.

\subsection{Phylogenetic analysis}

The amino acid sequences were aligned using the CLUSTAL program (Higgins and Sharp 1988). After removing gaps, the verified alignments were used to construct phylogenetic trees. The trees were calculated using MEGA program based on the neighbor-joining method (Saitou and Nei 1987; Kumar et al. 2001). The sequences used as follow: Human-CRLR, NP_005786; Pig-CRLR, Q867C1; Dog-CRLR, XP_545560; Mouse-CRLR, NP_061252; Xenopus-CRLR, NP_001016893; Fugu-CRLR2, BAE45313; Salmon-CRLR, CAD48406; Flounder-CRLR, AB035314; Fugu-CRLR1, BAE45312; Flounder-CTR, AB035315; Chicken-CTR， XP_425985; Bullfrog-CTR， Q28DX2; Fugu-CTR, BAE76018; Medaka-CTR, AAI19273; Pig-CTR, AAA31023; Mouse-CTR, AAI19273; Human-CTR, NP_001733; Dog-CTR, XP_539423; Ascidian-CTR, 
BAI63096; Human-CRHR1, NP_004373.

2.6. Analysis of the mRNA expression of both ray CRLR and CTR-like receptors in the gill and kidney after transfer to diluted seawater.

Seawater adapted-stingrays $(n=8$, both sexes) were gradually transferred into diluted seawater. In the first day, the stingrays were transferred to $80 \%$ seawater and then kept for 6 hours followed by putting them into $60 \%$ seawater for remaining of the day. In the next day, the stingray were kept in $40 \%$ seawater for 6 hours, and then transferred into $20 \%$ seawater. After keeping the stingrays in $20 \%$ seawater for 12 hours, the stingrays were anesthetized with ethyl 3-aminobenzoate, methanesulfonic acid salt (Sigma-Aldrich). The gill and kidney were collected from stingray under proper anesthetic condition. Also, the seawater-adapted stingrays ( $\mathrm{n}=8$, both sexes) were anesthetized with ethyl 3-aminobenzoate, methanesulfonic acid salt (Sigma-Aldrich). The gill and kidney were removed from the seawater stingrays.

Total RNA was prepared using a total RNA isolation kit for fibrous tissue and complementary DNA synthesis was performed (RNase Easy Fibrous Mini-Kit, Qiagen GmbH, Hilden, Germany). The real-time PCR amplification was analyzed with a BIO-RAD iCycler (BIO-RAD, Hercules, CA) using the primers for CRLR (5': GGAGAAGCTAAAGACAGCATTGACT; 3': CAGCAGCGAAGCCACTGATA') and for $\quad$ (5': $\quad$ GGAAAAGGTCACCAAGATTGC; $\quad$ 3': AGTCCATGTTCGGTTGCTCTCT). The annealing temperature in the amplification of both CRLR and CTR-like cDNAs was $63^{\circ} \mathrm{C}$. The amplified PCR products have been verified by sequencing to confirm its sequences. The detailed conditions of PCR were described in our previous study (Takahashi et al., 2007). The CRLR and CTR-like mRNA 
levels were normalized to the $\beta$-actin mRNA level measured by above described primer set (5’: TTGGCAATGAGCGATTCAGA; 3’: CACAGGATTCCATACCCAAGAAA).

\subsection{Statistical analysis}

Real-time PCR was performed and the data were analyzed using the Student's $t$-test. The significance level was $P<0.05$.

\section{Results and discussion}

\subsection{PCR amplification of two receptors in the brain of stingray}

Sequence analysis indicated that two types of cDNA fragments are amplified by PCR primer sets at the conserved regions of mammalian CRLR and CTR cDNA sequences. One cDNA fragment (422 bp) had high identity to flounder CRLR (73.4\%) and human CRLR (81.3\%) and to a lesser extent to flounder CTR (53.9\%) and human CTR (56.3\%). The second cDNA (422 bp) had high identity to both CRLR (to human 57.0\%; to flounder 48.3\%) and CTR (to human 59.4\%; to flounder 63.3\%). Thus, we believe that two receptors belong to the calcitonin-family receptors.

\subsection{RACE cloning and sequencing of two calcitonin-family receptors}

By RACE cloning, the full sequences of the two calcitonin-family receptors were determined. The open reading frame of one receptor cDNA coded a 525-amino acid protein (see, supplementary data). The amino acid identity of this receptor to CRLR was highest with human CRLR (64.5\%), frog (64.7\%), and flounder (61.2\%) and this was higher than the CTR of human (46.1\%), frog (54.7\%), or flounder (48.9\%). This strongly suggested that the obtained cDNA encodes CRLR in stingray. 
The amino acid identity of the second stingray receptor (see, supplementary data) was similar to CRLRs (human 50.5\%; frog 50.7\%; flounder 48.0\%) and CTRs of other species (human 43.2\%; frog 49.1\%; flounder 41.8\%). After alignment of flounder CRLR, flounder CTR, human CRLR, human CTR, and two stingray receptors, three potential sites (Asn-X-Ser/Thr) for N-linked glycosylation, which are conserved in mammalian CRLR and CTR, were identified in stingray receptors before the first putative transmembrane domain. Furthermore, 12 cysteines were conserved among CRLRs, CTRs, and stingray receptors. These glycosylation sites and cysteines are suggested to be important for ligand binding (Qi et al., 1997; Ho et al., 1999). Using BLAST against the DDBJ/NCBI protein database, furthermore, we confirmed that the sequences are most similar to CRLR and CTR. Thus, we concluded that two receptors belong to the calcitonin-family receptors.

\subsection{Phylogenetic analysis of calcitonin-family receptors}

The phylogenetic tree was determined for the known calcitonin-family receptors together with stingray receptors (see, supplementary data). As a result, the stingray receptors were located with CRLR and CTR in other animals. The first stingray receptor branched from teleost CRLR and composed of a clade of mammalian and xenopus CRLR. This result strongly supports that the amino acid sequence was that of stingray CRLR (ray CRLR). The second stingray receptor, co-located with flounder CTR, and was placed between the CRLRs clade and the non-mammalian CTRs clade (see, supplementary data).

We previously reported amino acid sequences of both CT and CGRP in flounder (Suzuki et al., 2001). The amino acid sequence of flounder CT was more similar to teleosts (78-100\%), salamander (81\%), reptiles (84\%), and chicken (84\%) than those of stingray (72\%) and frogs (56-78\%), and it is largely different from that of mammals 
(31-50\%). However, the predicted amino acid sequence of flounder CGRP was more conserved than CT among vertebrates and showed 78\%, 78\%, 78\%, 81\%, and 73-78\% identity to salmon, cod, frog, chicken, and mammalian CGRPs, respectively. Among vertebrates, CGRP is a well-conserved molecule during evolution while CT is quite varied. Corresponding to sequence changes in ligand (CT), the receptor (CTR) seems to be varied largely. Thus, it is highly likely that the second receptor is the stingray equivalent of CTR (ray CTR-like).

\subsection{Expression of ray CRLR and ray CTR-like mRNAs in different tissues}

Specific PCR products of ray CRLR mRNA were amplified from brain, gill, atrium and ventricle and detected in cartilage, pituitary gland, spleen, liver, gall-bladder, intestine, rectual gland, kidney, testis and ovary (Fig. 2). Pancreas did not show any expression with the present conditions (Fig. 2). The ray CRLR mRNA expression was found in brain, heart and intestine and this same as seen in mammals (Eysselein et al., 1991; Poyner, 1992), suggesting similar functions in those tissues. In spleen, relatively high expression of ray CRLR was detected. Arlot-Bonnemains et al. (1991) reported that CGRP-specific binding in trout tissues is high in the spleen although the function has not yet been elucidated. In the early development of gut in zebrafish, the number of nerve cell bodies and fibers gradually increased and CGRP was detected in these nerve cells (Olsson et al., 2008). In another study, cod CGRP $\left(10^{-9}-10^{-7} \mathrm{M}\right)$ inhibited the motility of spontaneously active ring preparations from the cod intestine (Shahbazi et al., 1998) suggesting that CGRP plays a role in fish gut development and physiology. The localization of CGRP in the stingray gut suggests that CGRP may have significant roles in its gut.

Recently, involvement of CGRP in the outgrowth of the gubernaculums has been noted, 
and it has been suggested to play a role in testicular descent in mammalians (Chan et al., 2009). CGRP released from the genitofemoral nerve causes maximal mitosis in the gubernacular bulb of mammals (Chan et al., 2009). In stingray, this hormone may involve in testicular development that regulating the balance between cell proliferation and apoptosis.

Specific PCR products of ray CTR-like mRNA were amplified from cartilage, brain, pituitary gland, gill, atrium, ventricle, pancreas, spleen, liver, gall bladder, intestine, rectal gland, kidney, testis, and ovary (Fig. 2). In the cartilage of stingray, we detected ray CTR-like mRNA expression. It has been reported that CT acts on mammalian cartilage and promotes synthesis (Karsdal et al., 2006; Sondergaard et al., 2006). In the stingray, thus, CT may function to the growth of cartilage. CT-immunoreactive cells were found in the intestine of goldfish and appeared to control absorption of nutrients (Okuda et al., 1999). Therefore, the presence of ray CTR-like mRNA in intestine corresponds well with this physiological role of CT in fish. Previously mRNA expression of salmon CTR was detected in brain and pituitary gland and this was consistent with another study in mammalian tissues (Azria, 1989) where it was suggested that CT might act as a neurotransmitter.

In female sharks, it had been shown that plasma CT levels were elevated during reproductive periods (Nichols et al., 2003). We previously reported that estrogen-specific-binding and estrogen receptor mRNA were present in the stingray ultimobranchial gland (CT secreting organ in sub-mammalian vertebrates) (Yamamoto et al., 1996). The possible involvement of CT in stingray reproductive physiology is implied because of the presence of this receptor in the ovary and testis of stingray in the present study.

Ray CRLR and ray CTR-like mRNAs were found to be expressed in the excretory 
organs such as gill, kidney and rectal gland. As this fish is euryhaline (de Vlaming and Sage, 1973; Janech et al., 2003; Evans et al., 2010) and CGRP functions to osmoregulation in teleosts (Lamharzi et al., 1996; Suzuki et al., 2002; Lafont et al., 2007), we examined ray CRLR and ray CTR-like mRNA expression in the gill and kidney when stingrays were transferred to the diluted seawater.

3.5. Changes in $m R N A$ expression of both ray CRLR and CTR-like receptors in the gill and kidney when transferred to diluted seawater

The results are shown in Fig. 3. The ray CTR-like mRNA expression in the gill and kidney was higher than the ray CRLR mRNA. These results coincided with the tissue specific expressions (Fig. 2). When stingrays were transferred to the diluted seawater (20\% seawater), both receptors mRNA expression significantly decreased in the gill. Similar results were obtained in the stingray kidney. When rainbow trout were adapted to seawater, their plasma CGRP levels and CGRP binding sites in the gill increased (Lamharzi et al., 1996). Similarly when flounder were moved from seawater to freshwater, CRLR mRNA expression decreased (Suzuki et al., 2002). Thus, CGRP may play a role in osmoregulation in teleosts (Lafont et al., 2007).

Interestingly, the plasma level of CT did not change when freshwater adapted eels were moved to $100 \%$ seawater (Suzuki et al., 1999). This was reflected in the study where the flounder were transferred from seawater to freshwater and CTR mRNA expression in the gill did not alter (Suzuki et al., 2002). Therefore, CT may play a role in osmoregulation in cartilaginous fish and not in teleosts, as CT has some functions in osmoregulation as the CTR-like mRNA expression in both stingray gill and kidney was decreased when the fish were transferred from seawater to freshwater. Further study is required to elucidate the 
possible roles of CT and CGPR in cartilaginous fish.

\subsection{Conclusions}

(1) cDNA encoding CRLR was cloned from the stingray brain. Tissue-expression analysis, using RT-PCR, indicated that ray CRLR mRNA was detected mainly in the nervous system (brain) and vascular system (atrium, ventricle, and gill), indicating that CGRP may play roles in the nervous and vascular systems as it does in mammals.

(2) Another receptor cDNA was cloned from the brain of stingray. Based on the data of multiple alignments, phylogenetic analysis and tissue distribution pattern, this receptor is CTR equivalent in stingray.

(3) When stingray transferred to the diluted seawater (20\% seawater), mRNA expression of both receptors were significantly decreased in the stingray gill. Similar results were obtained in the kidney. Thus, identification of two members of the calcitonin-family receptors in the stingray will assist in the elucidation of the physiological roles of these receptors and their ligands in cartilaginous fish.

\section{Acknowledgments}

This study was supported in part by grants to N.S. (Grant-in-Aid for Scientific Research (C) No. 21500404 by JSPS; Grant-in-Aid for Space Utilization by Japan Aerospace Exploration Agency), to A.H. (Grant-in-Aid for Scientific Research (C) No. 21570062 by JSPS), to T.S. (Grant-in-Aid for Scientific Research (C) No. 22570065 by JSPS), to M.O. (Grant-in-Aid for Encouragement of Scientists No. 22870020 by JSPS), and to K.H. [the Environment Research and Technology Development Fund (B-0905) by the Ministry of the Environment in Japan; Health and Labor Sciences Research Grants of 
Ministry of Health, Labor and Welfare, Japan; Grant-in-Aid for Scientific Research (B) No. 21390034 by JSPS]. This work was carried out in part as a joint-research in Japanese Association for Marine Biology (JAMBIO).

\section{References}

Amara, S.G., Jonas, V., Rosenfeld, M.G., Ong, E.S., Evans, R.M., 1982. Alternative RNA processing in calcitonin gene expression generates mRNAs encoding different polypeptide products. Nature 298, 240-244.

Arlot-Bonnemains, Y., Fouchereau-Peron, M., Jullienne, A., Milhaud, G., Moukhtar, M.S., 1991. Binding sites of calcitonin gene related peptide (CGRP) to trout tissues. Neuropeptides 20, 181-186.

Azria, M., 1989. In: The calcitonins: Physiology and Pharmacology, Karger, Basel.

Brain, S.D., Grant, A.D., 2004. Vascular actions of calcitonin gene-related peptide and adrenomedullin. Physiol. Rev. 84, 903-934.

Chan, J.J., Farmer, P.J., Southwell, B.R., Sourial, M., Hutson, J.M., 2009. Calcitonin gene-related peptide is a survival factor, inhibiting apoptosis in neonatal rat gubernaculum in vitro. J. Pediatr. Surg. 44, 1497-1501.

Eysselein, V.E., Reeve, J.R., Jr., Sternini, C., Cominelli, F., Davis, W.M., Davis, M.T., Lee, T.D., Ho, F.-J., Ridout, D., Shively, J.E., 1991. Structural characterization of calcitonin gene-related peptide purified from rabbit intestine. Peptides 12, 289-295.

Evans, A.N., Henning, T., Gelsleichter, J., Nunez, B.S., 2010. Molecular classification of an elasmobranch angiotensin receptor: Quantification of angiotensin receptor and natriuretic peptide receptor mRNAs in saltwater and freshwater populations of the Atlantic stingray. Comp. Biochem. Physiol. 157B, 423-431. 
Fouchereau-Peron, M., Arlot-Bonnemains, Y., Taboulet, J., Milhaud, G., Moukhtar, M.S., 1990. Distribution of calcitonin gene-related peptide and calcitonin-like immunoreactivity in trout. Regl. Pept. 27, 171-179.

Gibson, S.J., Polak, J.M., Bloom, S.R., Sabate, I.M., Mulderry, P.M., Ghatei, M.A., McGregor, G.P., Morrison, J.F.B., Kelly, J.S., Evans, R.M., Rosenfeld, M.G., 1984. Calcitonin gene-related peptide immunoreactivity in the spinal cord of man and of eight other species. J. Neurosci. 4, 3101-3111.

Higgins, D.G., Sharp, P.M., 1988. CLUSTAL: A package for performing multiple sequence alignment on a microcomputer. Gene 73, 237-244.

Husmann, K., Sexton, P.M., Fischer, J.A., Born, W., 2000. Mouse receptor-activity-modifying proteins $1,-2$, and -3: Amino acid sequence, expression and function. Mol. Cell. Endocrinol. 162, 35-43.

Ho, H.H., Gilbert, M.T., Nussenzveig, D.R., Gershengorn, M.C., 1999. Glycosylation is important for binding to human calcitonin receptors. Biochemistry 38, 1866-1872.

Jansz, H.S., Zandberg, J., 1992. Identification and partial characterization of the salmon calcitonin/CGRP gene by polymerase chain reaction. Ann. N. Y. Acad. Sci. 657, 63-69.

Janech, M.G., Fitzgibbon, W.R., Chen, R., Nowak, M.W., Miller, D.H., Paul, R.V., Ploth, D.W., 2003. Molecular and functional characterization of a urea transporter from the kidney of the Atlantic stingray. Am. J. Physiol. Renal. Physiol. 284, F996-F1005.

Karsdal, M.A., Tanko, L.B., Riis, B.J., Sondergard B.C., Henriksen, K., Altman, R.D., Qvist, P., Christiansen, C., 2006. Calcitonin is involved in cartilage homeostasis: Is calcitonin a treatment for OA? Osteoarthritis Cartilage 14, 617-624.

Kumar, S., Tamura, K., Jakobsen, I.B., Nei, M., 2001. MEGA2: Molecular evolutionary genetics analysis software. Bioinformatics 17, 1244-1245. 
Lafont, A.-G., Dufour, S., Fouchereau-Peron, M., 2007. Evolution of the CT/CGRP family: Comparative study with new data from models of teleosts, the eel, and cephalopod molluscs, the cuttlefish and the nautilus. Gen. Comp. Endocrinol. 153, 155-169.

Lamharzi, N., Fouchereau-Peron, M., 1996. Adaptation of rainbow trout to seawater: Changes in calcitonin gene-related peptide levels are associated with an increase in hormone-receptor interaction in gill membranes. Gen. Comp. Endocrinol. 102, 274-280 McLatchie, L.M., Fraser, N.J., Main, M.J., Wise, A., Brown, J., Thompson, N., Solari, R., Lee, M.G., Foord, S.M., 1998. RAMPs regulate the transport and ligand specificity of the calcitonin-receptor-like receptor. Nature 393, 333-339.

Molist, P., Rodriguez-Moldes, I., Batten, T.F.C., Anadon, R., 1995. Distribution of calcitonin gene-related peptide-like immunoreactivity in the brain of the small-spotted dogfish, Scyliorhinus canicula L. J. Comp. Neurol. 352, 335-350.

Mulderry, P.K., Ghatei, M.A., Rodrigo, J., Allen, J.M., Rosenfeld, M.G., Polak, J.M., Bloom, S.R., 1985. Calcitonin gene-related peptide in cardiovascular tissues of the rat. Neuroscience 14, 947-954.

Nichols, S., Gelsleichter, J., Manire, C.A., Cailliet, G.M., 2003. Calcitonin-like immunoreactivity in serum and tissues of the bonnethead shark, Sphyrna tiburo. J. Exp. Zool. A. Comp. Exp. Biol. 298, 150-161.

Okuda, R., Sasyama, Y., Suzuki, N., Kambegawa, A., Srivastav, A. K., 1999. Calcitonin cells in the intestine of goldfish and a comparison of the number of cells among saline-fed, soup-fed, or high Ca soup-fed fishes. Gen. Comp. Endocrinol. 113, 267-273.

Olsson, C., Holmberg, A., Holmgren, S., 2008. Development of enteric and vagal innervation of the zebrafish (Danio rerio) gut. J. Comp. Neurol. 508, 756-770.

Poyner, D.R., 1992. Calcitonin gene-related peptide: Multiple actions, multiple receptors. 
Pharmac. Ther. 56, 23-51.

Qi, L.J., Leung, A.T., Xiong, Y., Marx, K.A., Abou-Samra, A.-B., 1997. Extracellular cysteines of the corticotropin-releasing factor receptor are critical for ligand interaction. Biochemistry 36, 12442-12448.

Rosenfeld, M.G., Mermod, J.-J., Amara, S.G., Swanson, L.W., Sawchenko, P.E., Rivier, J., Vale, W.W., Evans, R.M., 1983. Production of a novel neuropeptide encoded by the calcitonin gene via tissue-specific RNA processing. Nature 304, 129-135.

Saitou, N., Nei, M., 1987. The neighbor-joining method: A new method for reconstructing phylogenetic trees. Mol. Biol. Evol. 4, 406-425.

Sexton, P.M., Albiston, A., Morfis, M., Tilakaratne, N., 2001. Receptor activity modifying proteins. Cell. Signal. 13, 73-83.

Shahbazi, F., Karila, P., Olsson, C., Holmgren, S., Conlon, J.M., Jensen, J., 1998. Primary structure, distribution, and effects on motility of CGRP in the intestine of the cod Gadus morhua. Am. J. Physiol. Regul. Integr. Comp. Physiol. 275, R19-28.

Sondergaard, B.C., Wulf, H., Henriksen, K., Schaller, S., Oestergaard, S., Qvist, P., Tankó, L.B., Bagger, Y.Z., Christiansen, C., Karsdal, M.A. 2006. Calcitonin directly attenuates collagen type II degradation by inhibition of matrix metalloproteinase expression and activity in articular chondrocytes. Osteoarthritis Cartilage 14,759-768.

Suzuki, N., Eguchi, C., Hirai, T., Sasayama, Y., 1997. Nucleotide sequences of reptile calcitonins: Their high homology to chicken calcitonin. Zool. Sci. 14, 833-836.

Suzuki, N., Suzuki, D., Sasayama, Y., Srivastav, A. K., Kambegawa, A., Asahina, K., 1999. Plasma calcium and calcitonin levels in eels fed a high calcium solution or transferred to seawater. Gen. Comp. Endocrinol. 114, 324-329.

Suzuki, N., Suzuki, T., Kurokawa, T., 2000. Cloning of a calcitonin gene-related peptide 
receptor and a novel calcitonin receptor-like receptor from the gill of flounder, Paralichthys olivaceus. Gene 244, 81-88.

Suzuki, N., Suzuki, T. and Kurokawa, T., 2001. Cloning of a calcitonin gene-related peptide from genomic DNA and its mRNA expression in flounder, Paralichthys olivaceus. Peptides 22, 1435-1438.

Suzuki, N., Suzuki, T. and Kurokawa, T., 2002. Possible involvement of calcitonin gene-related peptide in seawater adaptation of flounder: Expression analysis of its receptor mRNA in the gill. Fisheries Sci. 68, 425-429.

Takahashi, H., Prunet, P., Kitahashi, T., Kajimura, S., Hirano, T., Grau, E.G., Sakamoto, T., 2007. Prolactin receptor and proliferating/apoptotic cells in esophagus of the Mozambique tilapia (Oreochromis mossambicus) in fresh water and in seawater. Gen. Comp. Endocrinol. 152, 326-331.

De Vlaming, V.L., Sage, M., 1973. Osmoregulation in the euryhaline elasmobranch, Dasyatis Sabina. Comp. Biochem. Physiol. 45A, 31-44.

Wimalawansa, S.J., 1997. Amylin, calcitonin gene-related peptide, calcitonin, and adrenomedullin: A peptide superfamily. Crit. Rev. Neurobiol. 11, 167-239.

Yamamoto, K., Suzuki, N., Takahashi, N., Sasayama, Y., Kikuyama, S., 1996. Estrogen receptors in the stingray (Dasyatis akajei) ultimobranchial gland. Gen. Comp. Endocrinol. 101, 107-114. 


\section{Figure Legends}

Fig. 1. Location and sequence of primers. The CRLR and CTR molecules have four extracellular domains (Ecd) 1-4, seven transmembrane domains (Tmd 1-7), and for intracellular domains (Icd 1-4). The PCR primers were designed to the highly conserved region of the mammalian CRLR and CTR cDNA sequences.

Fig. 2. Tissue specific expression of ray CRLR and ray CTR-like mRNAs by RT-PCR. After PCR amplification, the PCR products were analyzed on 2.5\% NuSive GTG agarose gel (FMC Bioproducts, ME, USA) and stained with ethidium bromide.

Fig. 3. Changes in mRNA expression of both ray CRLR and CTR-like receptors in the gill (A) and kidney (B) when transferred to diluted (20\%) seawater. * indicates statistically significant difference at $P<0.05$ from the values in the control. The data expressed as mean \pm SEM $(n=8)$. 


\section{Supplementary data of Legends}

Fig. 1. Nucleotide and deduced amino-acid sequences of ray CRLR cDNA. The nucleotide sequence obtained by PCR using a 5'B/3'B primer set is shown in bold. The boxes and underlining indicate the location of 5' RACE primers and 3' RACE primers, respectively. The stop codon TGA is indicated by the asterisk. This data has been available under Genbank accession no. AB665754.

Fig. 2. Nucleotide and deduced amino-acid sequences of ray CTR-like cDNA. The nucleotide sequence obtained by PCR using a 5'B/3'B primer set is shown in bold. The boxes and underlining indicate the location of 5' RACE primers and 3' RACE primers, respectively. The stop codon TGA is indicated by the asterisk. This data has been available under Genbank accession no. AB665755.

Fig. 3. Multiple alignment of the amino-acid sequences of flounder CRLR (fCRLR), flounder CTR (fCTR), human CRLR (hCRLR), human CTR (hCTR), stingray CRLR (ray CRLR), and stingray CTR-like (ray CTR-like). Deletion of amino-acid residues is indicated by dashes. Conserved amino-acid residues at least three sequences are indicated by shaded areas. Underlining indicate putative transmembrane domains I to VII. \# and * indicate potential $\mathrm{N}$-linked glycosylation sites and cysteine residues commonly to these receptors, respectively. DDBJ/EMBL/GenBank accession numbers are as follow: fCRLR (AB035314), fCTR (AB035315), hCRLR (NP_005786), hCTR (NP_001733), ray CRLR (AB665754), and ray CTR-like (AB665755). 
Fig. 4. Phylogenetic tree of CRLRs and CTRs constructed by the neighbor-joining method. The number beside each branch indicates the percentage of times that a node was supported in 1000 bootstrap pseudoreplications. The scale bar indicates an evolutionary distance of 0.1 amino acid substitutions per protein. 


\section{Location of primer sets}

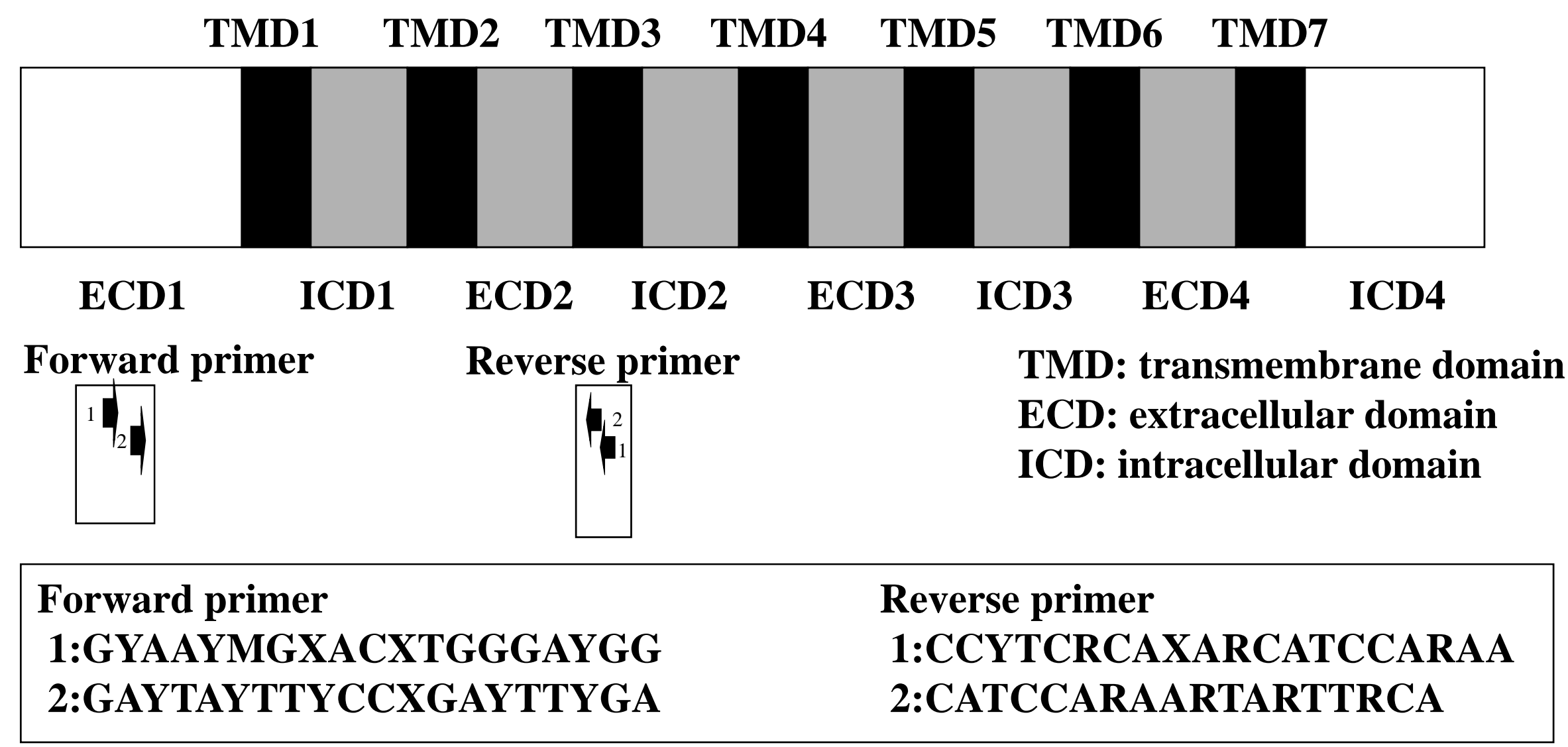



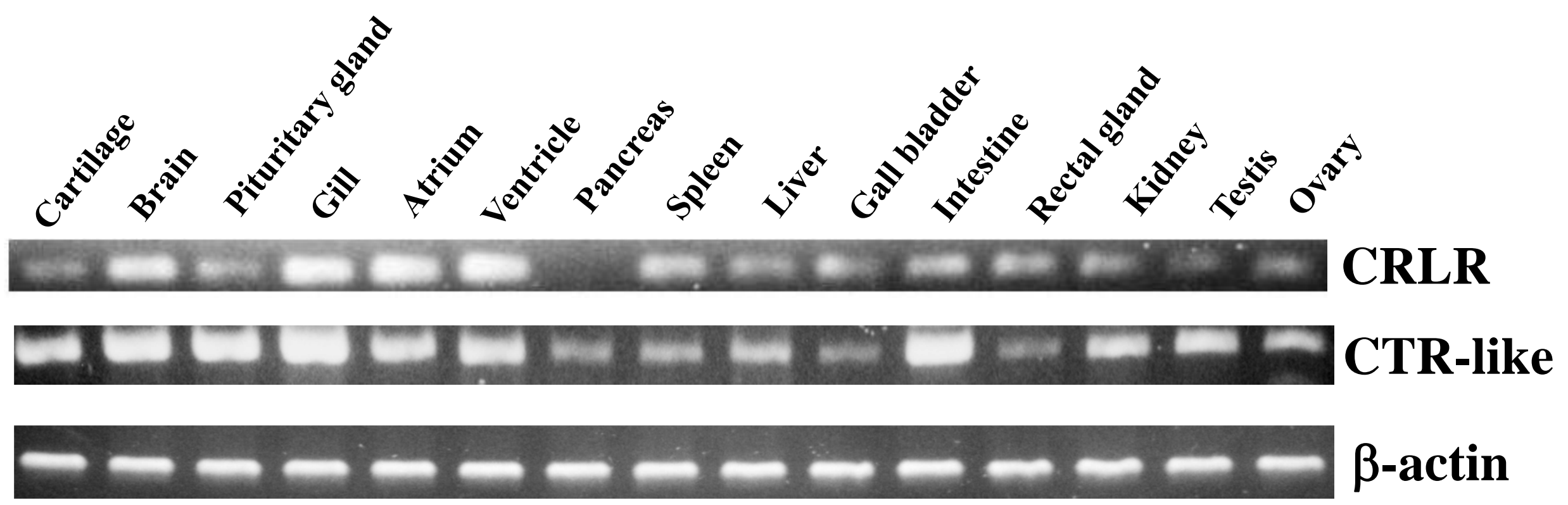

Figure 2Suzuki et al. 


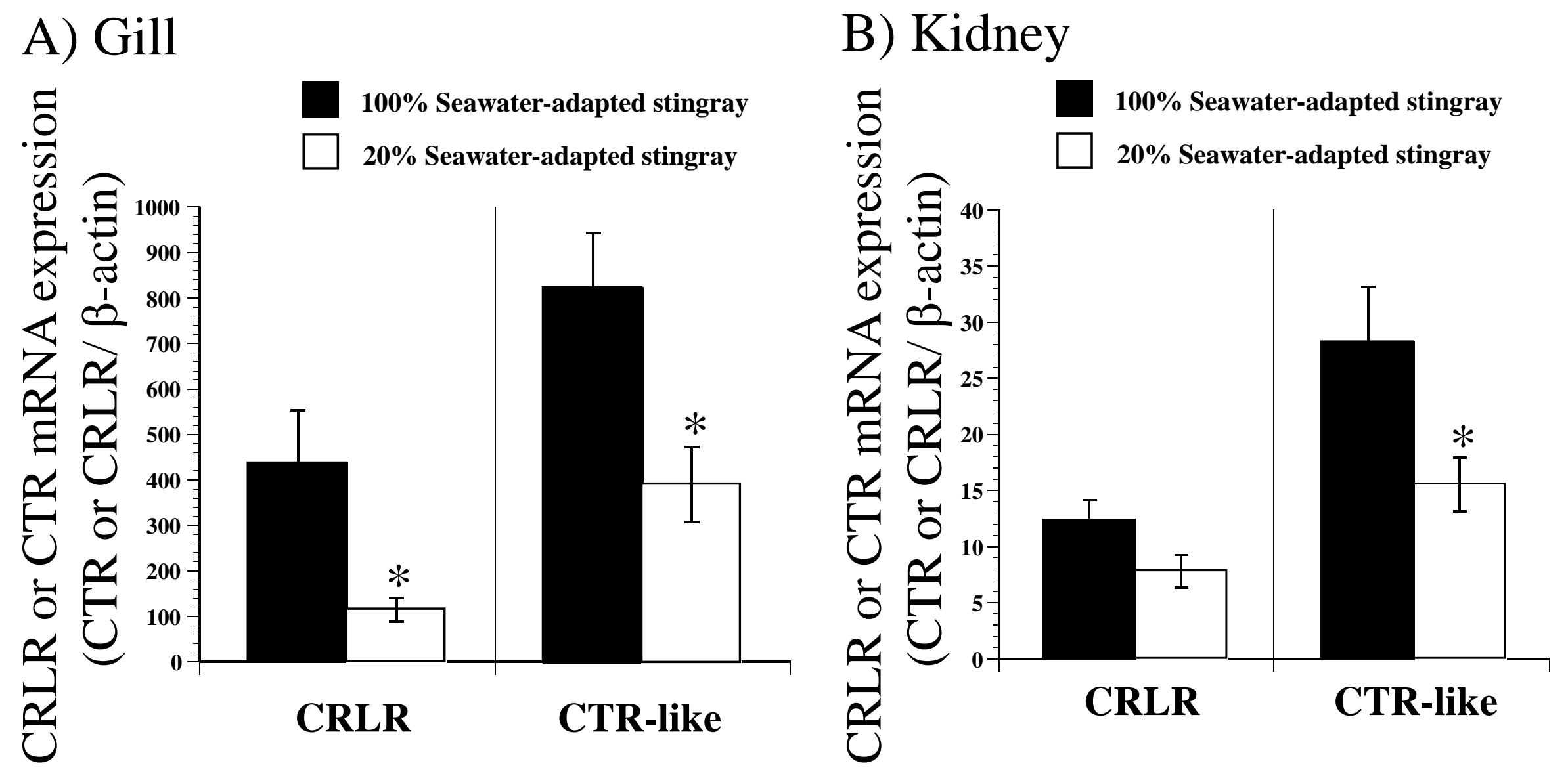

Figure 3 Suzuki et al. 